\title{
ANALYSIS OF THE NEED FOR HEALTH WORKERS USING WORK- LOAD INDICATOR STAFFING NEED (WISN) METHOD IN INPATIENT SERVICES IN REGIONAL GENERAL HOSPITAL OF BUTON UTARA REGENCY IN 2021
}

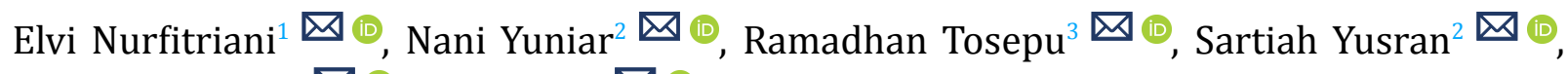
Asnia Zainuddin $^{2}$ (1) and Suhadi ${ }^{2}$ (1)

${ }^{1}$ Regional General Hospital, North Buton Regency, Southeast Sulawesi, Indonesia

${ }^{2}$ Public Health Study Program, Faculty of Public Health, Universitas Halu Oleo, Indonesia

${ }^{3}$ Department of Public Health Magister Study Program, Universitas Halu Oleo, Indonesia

Received 2 July 2021

Accepted 16 July 2021

Published 31 July 2021

Corresponding Author

Nani Yuniar, naniyuniar0509@gm ail.com

DOI $10.29121 /$

granthaalayah.v9.i7.2021.4077

Funding: This research received no specific grant from any funding agency in the public, commercial, or not-for-profit sectors.

Copyright: (C) 2021 The Author(s). This is an open access article distributed under the terms of the Creative Commons Attribution License, which permits unrestricted use, distribution, and reproduction in any medium, provided the original author and source are credited.

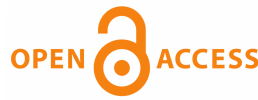

\section{ABSTRACT}

Motivation/Background: The ratio of the number of doctors to the population in North Buton is 1:2135. Meanwhile, the ratio of the number of nurses to the population is 1:308. This number is not in accordance with the standards stipulated in the Decree of the Minister of Health No.81/Menkes/SK/I/2004. Menkes (2004)

Method : This research used Workload Indicator Staffing Need (WISN) method in inpatient services at the Regional General Hospital of Buton Utara.

Results: The workload of specialist doctors at the Regional General Hospital of Buton Utara in the Obstetrics and Gynecology Treatment room could be handled by two specialist doctors, while each of the Child Care room, Internal Medicine room, and Surgery room was handled by one specialist doctor. The number of nurses needed was 9 people, and the number of midwives needed was 11 people.

Conclusions: The Regional General Hospital of Buton Utara is still lacking health workers, and this condition causes a high workload on medical services. This fact results in the quality of health services at the Regional General Hospital of Buton Utara not being optimal. This hospital requires one specialist doctor, 4 nurses, and 4 midwives for the Obstetrics and Gynecology Treatment room.

Keywords: Need for Health Workers, WISN Method, Inpatient Services

\section{INTRODUCTION}

Human Resource Planning (HRP) is an activity to collect and to use the information to support resource investment decisions in various human resources activities. Human Resource for Health (HRH) Planning is conducted based on the need 
for health development at local, national, and global levels. The need for HRH can be calculated based on three methods, namely workload analysis, minimum manpower standards, and population ratio "33, P. R. N. Permenkes RI Nomor 33 Tahun 2015. CNR-ISTI Technical Report" (2015). Workload analysis is a management technique that is carried out systematically to gain information about the level of work effectiveness and efficiency based on work volume Wanri et al. (2018). A more complete regulation of health workers is currently stipulated in the Law on Health Workers, which classified health workers into thirteen, namely medical personnel, clinical psychologists, nurses, midwives, pharmacists, public health workers, environmental health workers, nutritionists, physical therapy personnel, medical technicians, biomedical technical personnel, traditional health workers, and other health workers Fadhillah et al. (2019), Pramono and Mariska (2017) Meanwhile, the need for non-health HRH is adjusted to the need for the existing health facilities Wangi et al. (2019).

It is explained Arifudin et al. (2017), that the number of health workers in Indonesia is still very small compared to the total population of Indonesia. Based on data from HRH of the Ministry of Health, the number of health workers in Indonesia has increased every year Menkes (2004) . Data of the Indonesia Health Profile in 2018 showed that the number of health workers in 34 provinces in Indonesia was 886,488 people (increased by $5.98 \%$ from 2017) consisting of 15 different categories of health workers, and the number of health support personnel was 296,320 people (decreased by $3.48 \%$ from 2017) (The Ministry of Health of Republic of Indonesia, 2018).

Based on the data obtained from Statistics Indonesia of Sulawesi Tenggara, the number of health workers of the state civil apparatus in 2018 is 11,677 workers. Buton Utara has a total of 513 health workers with State Civil Apparatus (ASN) status, which in this case consists of doctors, nurses, midwives, pharmacists, and nutritionists, of which there are 30 doctors, 208 nurses, 215 midwives, 40 pharmacists, and 20 expert's nutrition, which all of these health workers are scattered throughout the Buton Utara regency (, 2020). Based on the data obtained from Statistics Indonesia for Buton Utara (2020), the population of Buton Utara in 2019 was 64,072 people, consisting of 32,307 men and 31,765 women. By looking at the ratio of the number of health workers to the population in North Buton, it can be seen that the ratio of doctors is 1:2135, while the ratio of nurses is $1: 308$ Bps (2020). This number is not in accordance with the standards set out in the Decree of the Minister of Health No.81/Menkes/SK/I/2004 where the ratio between doctors and the population is 96 per 100,000 population or $1: 1041$, while nurses are 158 per 100,000 population or 1:632 in 2019 Menkes (2004) .

Hospital, as one of the advanced level referral health service facilities, has the aim of providing health services in a promotive, preventive, curative, and rehabilitative manner Swari et al. (2019). The condition of staffing management at the Regional General Hospital of Buton Utara in the field of basic health services currently has not met the standards set by the government, so it is necessary to carry out an in-depth 
analysis of the needs for workers according to their workload.

By knowing the right number of workers at the Regional General Hospital of Buton Utara, it is expected that basic health services at the hospital be more optimal and be able to support the progress of the Regional General Hospital of Buton Utara in terms of employee management.

\section{MATERIALS AND METHODS}

This study used a qualitative approach applying the method of observation, interview guidelines, and document review. To obtain the amount of time spent on each activity pattern of doctors, nurses, and midwives, the Work Sampling technique was used. In this case, the activities of the staff/employees in question are observed and then examined every 10 minutes for 6 working days. The use of the productive time obtained is then used to calculate the need for workers using the WISN (Workload Indicator Staffing Need) method, which is then analyzed against the results of the workload and the workers that have been obtained to determine strategies in meeting the needs of doctors, nurses, and midwives in services in inpatient services at the Regional General Hospital of Buton Utara in 2020.

The subjects consisted of the key informants, namely the Director of the Regional General Hospital of Buton Utara, The Head of Hospital Administration, the Head of Nursing Unit, and the other informants like specialist doctors, midwives, and nurses.

The stages of data analysis were carried out in 2 stages, namely:

- Calculating the proportion of productive activity

1. Data of worker's activities were obtained from the results of the observation and recording of health worker's activities, and then the data were grouped into productive activities consisting of direct activities, indirect activities, personal activities, and non-productive activities.

2. The percentage of each activity group is made in tabular form.

3. The proportion of productive activity per day was calculated.

- Calculating the number of health workers needed in the inpatient service unit at the Regional General Hospital of Buton Utara, the results of the observations would use the work sampling method as the basis for calculating the WISN (Workload Indicator Staff Need), which is the procedure for calculating the number of health workers needed based on workload indicators.

\section{RESULTS AND DISCUSSIONS}

The results showed that there was a discrepancy between the workload of health workers and the availability of health workers at the Regional General Hospital of Buton Utara. The number of representative health workers as human resources at the Regional General Hospital of Buton Utara is presented as follows: 
Table 1 Work Units and HR Categories in Inpatient Services at the North Buton District Hospital in 2021

\begin{tabular}{ccc}
\hline Sub Unit Work / Room & $\begin{array}{c}\text { Health Human } \\
\text { Resources } \\
\text { dr. Sp.OG }\end{array}$ & $\begin{array}{c}\text { Amount Available Human } \\
\text { Resources }\end{array}$ \\
\hline $\begin{array}{c}\text { Obstetrics and Gynecology } \\
\text { Care }\end{array}$ & 1 \\
\hline Perinatology Care/Child & Str.Keb & 5 \\
& dr. Sp. A & 1 \\
\hline AMK & 1 \\
\hline Anternal Medicine Care & Amd.Keb & 3 \\
& dr. Sp.PD & 1 \\
\hline dr. Umum & 1 \\
& AMK & 1 \\
\hline & dr. Sp.B & 3 \\
\hline & dr.Umum & 1 \\
\hline
\end{tabular}

The diagram shows that the distribution of human resources in North Buton Hospital was mostly in the Obstetrics and Gynecology Treatment Room, where there were 7 human resources including one obstetrician. The Surgical Treatment Unit had the least distribution of human resources, namely three human resources consisting of a specialist doctor, general practitioner, and nurse. Meanwhile, the Internal Medicine Room was dominated by general practitioners with three people, and the Pediatric Treatment Room did not have general practitioner. The dominance of one treatment room was the impact of varying community demands. This indirectly showed that the basic health services at the Regional General Hospital of Buton Utara were mostly focused on obstetric services. Based on the principle of Human Resource Planning, this is a reasonable implication, as stated by Wardanis (2018) that the accuracy of the number of workers in a production system is a basic condition that must be considered in preparing work designs. In other words, the number of human resources provided in each service unit is not always the same but is based on the factual needs of the hospital.

The Health Personnel Gap Ratio is a comparison between the available health workers and the proper need for health workers after a workload analysis is carried out. Based on the results of data analysis, it was shown that there was a difference between the number of health workers needed and those available at the Regional General Hospital of Buton Utara. The ratio of the gaps in health workers at the Regional General Hospital of Buton Utara is as follows: 
Table 2 The ratio of WISN Health workersto Specialists, Midwives,and Nurses in the Inpatient Installation of the Regional GeneralHospital of Buton Utara in 2021

\begin{tabular}{cccc}
\hline Health Workers & $\begin{array}{c}\text { The Available } \\
\text { Number (a) }\end{array}$ & $\begin{array}{c}\text { The Need based on the Calculation } \\
\text { of WISN (b) }\end{array}$ & $\begin{array}{c}\text { Ratio } \\
\text { (a/b) }\end{array}$ \\
\hline Pediatrician & 1 & 1 & 1 \\
\hline Obstetrician & 1 & 2 & 0.5 \\
Internal Medicine & 1 & 1 & 1 \\
Specialist & & 1 & 0 \\
\hline Surgeon & 0 & 9 & 0.56 \\
Nurse & 5 & 11 & 0.64 \\
\hline Midwife & 7 & & \\
\hline
\end{tabular}

Based on the calculation results, it was shown that the availability of pediatrician and internal medicine specialist at the Regional General Hospital of Buton Utara was in accordance with the workload needs, but the availability of obstetrician specialists, nurses, and midwives at the Regional General Hospital of Buton Utara still have not met the needs of the Regional Hospital according to the workload calculation.

Based on the workload analysis determined by the planning department at the Regional General Hospital of Buton Utara, every worker should have a greater productive working time. However, based on observations during the research process, it was found that there were still many employees who seemed busy with nonproductive works or other works that were not related to their main activities, especially nurses in the pediatric nursing room and midwives in the

midwifery room. Based on the calculation results from observations, it was shown that the productive time used by nurses was only $73.33 \%$, and the productive time used by midwives was only $72.73 \%$. This number is still far below the standard set by the ILO (1983) which states that workers are allowed to interrupt during working hours at $15 \%$ of the working time they should. This is similar to the findings Permatasari and Damayanti (2017) which concluded that all doctors, midwives, nurses at the Surabaya Pacarkeling Health Center had an underload category of workload with an average productive working time of $69.46 \%$ per day. This condition requires special attention from the management, as conveyed by (Kurnia Sari \& Maria Rosa, 2016) that, in terms of deviations from productive activities, the relevant management needs to consider optimizing the performance of the existing human resources.

Based on the results of the study, it was known that the Obstetrics and Gynecology Specialist Doctors and Midwives were available in the Obstetrics and Gynecology Hospital and Midwives. The calculation of working time available for specialist doctors was 1422.4 hours/person/year or 256,032 minutes/person/year while the working time of midwives was 4749.12 hours/person/year or 284,947 minutes/person/year. Internal Medicine Room had Internal Medicine Specialists and nurses, and the calculation of working time available for specialists was 1422.4 hours/person/year or 256,032 minutes/person/year while the working time of nurses is 4749.12 
hours/person/year or 284,947 minutes/person/year. The Surgical Treatment had general practitioner and nurses, and the calculation of working time available for general practitioner was 1400 hours/person/year or 252,000 minutes/person/year, while the working time of nurses was 4749.12 hours/person/year or 284,947 minutes/person/year. This amount is much larger than the finding Soesanto and Ersyad (2019) that based on the calculation of the need for nurses using the Workload Indicator of Staff Need (WISN), it is shown that the available working time is 1,954 hours/year (117,240 minutes/year), or 279.1 working days.

When calculated using the WISN ratio, the number of the existing health workers in December when compared to the number of health workers needed according to WISN method has not met the requirement, among others, the ratio of obstetricians needed in the Obstetrics and Gynecology Treatment room based on the results of WISN calculation with the current amount was 0.5 or $50 \%$. This means that there is still a shortage of $50 \%$ or 1 obstetrician in the Obstetrics and Gynecology Treatment room at the North Buton Hospital. This condition results in an excessive workload for the obstetricians at the North Buton Hospital, and under certain conditions will result in the quality of services provided. Based on what was stated by Alam et al. (2018), an inappropriate workload when viewed from the aspect of the number of activities carried out by medical personnel, both specialist doctors and other medical personnel, can cause stress and result in the quality of services provided to patients as recipients of the health services. This means that there was still a shortage of $50 \%$ or 1 obstetrician in the Obstetrics and Gynecology Treatment room at the Regional General Hospital of Buton Utara. This condition results in an excessive workload for the obstetrician at the hospital, and under certain conditions

will result in the quality of services they provide. Based on the statement of Alam et al. (2018), an inappropriate workload when viewed from the aspect of the number of activities carried out by medical personnel, both specialist doctors and other medical personnel, can cause stress and result in the quality of services provided to patients as recipients of the health service. This is also in line with the opinion $S$ and Tahir (2020) that the volume of work that is not in accordance with the nurses' abilities will cause them to work extra in fulfilling nursing services to patients. This condition will trigger nurses' emotional exhaustion due to these activities, which in turn will have an impact on their performance.

The discrepancy in the workload of health workers at the Regional General Hospital of Buton Utara also occurred in midwives and nurses, where the ratio of the number of midwives needed to the current one was 0.64 or $64 \%$ (excluding the head of the room). This means that there was still 36\% shortage of midwives or 4 people according to the workload of midwives at the Regional General Hospital of Buton Utara. The condition of work overload was also found by Mading and Willa (2019) who revealed that the workload of health workers at the first level of health facilities was quite large; they commonly multitask and sometimes work overtime. Meanwhile, the number of nurses available at the Regional General Hospital of Buton Utara 
was also not in accordance with the number needed based on the results of WISN calculation, where the comparison was 0.56 or $56 \%$. It means that there was still a shortage of $44 \%$ or 4 people to take the available workload at the Regional General Hospital of Buton. The results of this study are in accordance with research Harijanto et al. (2014) stating that there is an excess of more than $25 \%$ of workers at HVA Toeloengredjo Hospital.

The shortage of health workers can also be seen from the shift activities carried out by midwives in the obstetrics and gynecology care room where the shift should be carried out by a minimum of two people, but it appears to be carried out by one midwife, and the rest is filled by hospital contract staff. As the number of hours of patient care for 24 hours increases, the need for the number of health workers will also increase. This means that the more hours of patient care for 24 hours, the more the number of health workers needed by inpatients at the hospital. The increased workload will have an impact on the physical and mental condition of health workers, as stated by Alam et al. (2018), that the fulfillment of HR needs has the effect of a high workload on the workers and results in decreased job satisfaction, increased burnout incidents, increased desire to change jobs, and decreased service quality. Health workers who experience fatigue at work can cause work irregularities that will cause poor work performance.

The shortage of nurses in the adult inpatient room can be due to several nursing activities that have not been identified properly, increasing the workload of nurses in the adult inpatient room. This study also shows that identifying nursing activities that did not exist before would expectedly be able to show a shortage of nurses, the condition that will cause poor performance of a health worker in providing services in hospitals. The number of patients treated, including the classification of patients, will affect the workload that will be carried out by each health

worker. Therefore, it will also be related to the nursing care that will be provided by health workers to patients. As stated by S and Tahir (2020) the incompatibility of the ratio of the number of nurses to the number of patients will further increase the workload of nurses in the room.

\section{CONCLUSIONS AND RECOMMENDATIONS}

The number of health workers needed in inpatient services at the Regional General Hospital of Buton Utara as specialist doctors in the Obstetrics and Gynecology Treatment Room is 2 people and 1 specialist each in the Pediatrics/Perinatology Room, Internal Medicine Room, and Surgery Room. Meanwhile, the number of nurses needed is 9 people and the number of midwives required is 11 people. The HRH planning the Regional General Hospital of Buton Utara needs to be adjusted by adding 1 obstetrician, 1 internal medicine specialist, 1 pediatrician, 1 surgeon, 1 anesthesiologist, 4 midwives, and 4 nurses. 


\section{ACKNOWLEDGEMENTS}

We would like to thank all parties involved and supporting this research activity, especially the Rector of Universitas Halu Oleo Kendari who has permitted us to carry out this research. We also express our gratitude to the Chairman of the Public Health Study Program at Universitas Halu Oleo Kendari who has always provided support so that this research can be finished properly.

\section{REFERENCES}

33, P. R. N. Permenkes RI Nomor 33 Tahun 2015. CNR-ISTI Technical Report. (2015).

Alam, S., Raodhah, S., \& Surahmawati, S. (2018). Analysis of the Needs of Health Workers (Paramedics) Based on Workload Using the Workload Indicator Staffing Needs (WISN) Method at the Ass-Syifah Polyclinic UIN Alauddin Makassar. The Public Health Science Journal(2), 216-226. Retrieved from https://doi.org/10.24252/as.v10i2.6903

Arifudin, A., Sudirman, S., \& Andri, M. (2017). Evaluation of the Human Resource Management System in the Work Placement of Officers at Upt Puskesmas Lembasada. Promotif: Jurnal Kesehatan Masyarakat. Retrieved. Retrieved from D0I:10.31934/promotif.v7i1.20

Bps. (2020). Southeast Sulawesi in Figures. In the report.

Fadhillah, H., Wahyati, E., \& Sarwo, B. (2019). Regulation of Health Workers in the legislation and the principle of legal certainty. Soepra Jurnal Hukum Kesehatan, 5(1). Retrieved from https://doi.org/10.24167/shk.v5i1.1653

Harijanto, W., Moestopo, F. R., Nawa, N., \& Indah, Y. (2014). Manpower Needs at HVA Toeloengredjo Hospital using the Workload Indicators of Staffing Need (WISN) Method for Human Resource Efficiency. Jurnal Kedokteran Brawijaya, 28(1), 41-46. Retrieved from http://dx.doi.org/10.21776/ub.jkb.2014.028.01.21

ILO. Encyclopedia Of Occupational Health and Safety. Vol II. International Journal of Industrial Ergonomics. (1983)., 3(2).

Kemenkes, R. . N., \& Rosa, E. (2016). Calculation of Manpower Using the Workload Indicator Method of Personnel Needs (WISN) at PKU Muhammadiyah HospitalTemanggung. BERDIKARI: Jurnal Inovasi Dan Penerapan Ipteks, 4(2), 112-123. Retrieved from https://doi.org/10.18196/bdr.4212

Mading, M., \& Willa, R. W. (2019). Perception of the Workload of Health Center Health Workers. Buletin Penelitian Kesehatan, 48(3), 119-226. Retrieved from https://doi.org/10 .22435/bpk.v48i3.3306

Menkes, R. I. (2004). Decree of the Minister of Health of the Republic of Indonesia Number: 81/MENKES/SK/I/2004 concerning Guidelines for the Preparation of Health Human Resources Planning at the Provincial, Regency/City and Hospital. Jakarta. Retrieved from http://www.rstuguibu.com/files/KMK/81\%20TAHUN\%202004.pdf

Permatasari, E. D., \& Damayanti, N. A. (2017). Analysis of the Workload of Health Workers at the Surabaya Boyfriend Health Center. Jurnal Manajemen Kesehatan Indonesia, 5(3), 65-73. Retrieved from https://doi.org/10.14710/jmki.5.3

Pramono, A. Y., \& Mariska, A. (2017). The Role of Licensure in Breastfeeding Support in Indonesia. Journal of Human Lactation, 33(4), 745-747. Retrieved from https://dx.doi .org/10.1177/089033441772652610.1177/0890334417726526

S, I., \& Tahir, R. (2020). Analysis of the Workload of Implementing Nurses in the Inpatient Room at Bahteramas General Hospital, Southeast Sulawesi. Jurnal Kesehatan Man- 
arang, 6(1), 62-68. Retrieved from https://doi.org/10.33490/jkm.v6i1.142

Soesanto, D., \& Ersyad, T. (2019). Calculation of Nursing Personnel Needs Based on Foreign Students at Rs. Gotong Royong. Journal of Health Sciences, 12(02), 71-79. Retrieved from https://doi.org/10.33086/jhs.v12i02.554

Swari, S. J., Alfiansyah, G., Wijayanti, R. A., \& Kurniawati, R. D. (2019). Analysis of Completeness of Completion of Medical Record Files for Inpatients Dr. Kariadi Semarang. ARTERI: Jurnal Ilmu Kesehatan, 1(1), 50-56. Retrieved from https://doi.org/10.37148/ arteri.v1i1.20

Wangi, N. W. S., Agusdin, A., \& Nurmayanti, S. (2019). Analysis of Human Resource Planning (HR) for Health Centers with the Workload Method of Personnel Needs Indicators (Wisn) in West Lombok Regency. Jurnal Kedokteran, 5(1), 108-124. Retrieved from http://dx.doi.org/10.36679/kedokteran.v5i1.134

Wanri, A. W., Rahayu, S., \& Trigono, A. (2018). Analysis of Administrative Personnel Needs Based on Workload With Work Sampling Technique Using WISN Method in Order to Improve Quality of Outpatient Service Unit Rs. Jambi Bratanata. Jurnal Kesmas Jambi, 2(2), 20-32. Retrieved from https://doi.org/10.22437/jkmj.v2i2.6551

Wardanis, D. T. (2018). Workload Analysis of Surgical Hospital Medical Record Staff Surabaya Using the FTE Method. Jurnal Administrasi Kesehatan Indonesia, 6(1), 53-60. Retrieved from http://dx.doi.org/10.20473/jaki.v6i1.2018.53-60 